ENTREPRENEURSHIP AND SUSTAINABILITY ISSUES

ISSN 2345-0282 (online) http://jssidoi.org/jesi/

2019 Volume 7 Number 2 (December)

http://doi.org/10.9770/jesi.2019.7.2(53)

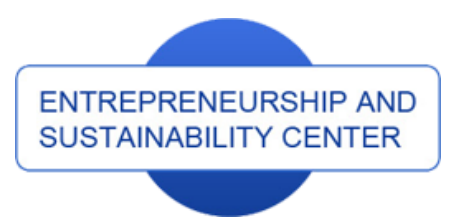

Publisher

http://jssidoi.org/esc/home

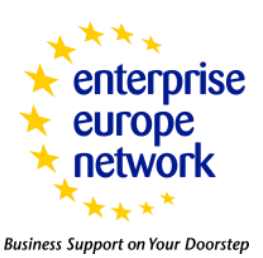

CASPA

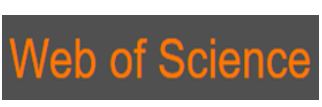

1 Clarivate

Analytics

\title{
MAJOR SOURCES OF FINANCING INVESTMENT PROJECTS
}

\author{
Baglan Aimurzina ${ }^{1}$, Mazken Kamenova ${ }^{2}$, Ainura Omarova ${ }^{3}$, Gulmira Bodaubayeva ${ }^{4}$, \\ Asel Dzhunusova ${ }^{5}$, Gulmira Kabdullina ${ }^{6}$ \\ 1,2,5 Kazakh University of Economics, Finance and International Trade, Zhubanova 7 street, Astana, Kazakhstan \\ ${ }^{3}$ Karaganda Economic University of Kazpotrebsoyuz, Akademicheskaya 9 Street, Karaganda, Kazakhstan \\ ${ }^{4}$ University of International Business, Abay 8 Street, Almaty, Kazakhstan \\ ${ }^{6}$ South Ural State University (National Research University), Chelyabinsk, Lenin Avenue 76, Russia \\ E-mails:.' aimurzina@mail.ru ; ${ }^{2}$ mazken_kamenova@mail.ru; \\ ${ }^{3}$ ainuraphd@mail.ru; ${ }^{4}$ gulmira.ba@mail.ru; ${ }^{5}$ asel.zhunusowa@mail.com, ${ }^{6}$ Asilhan1996@mail.ru
}

Received 16 May 2019; accepted 10 November 2019; published 15 December 2019

\begin{abstract}
The article describes the main sources of financing investment projects of small and medium-sized businesses (hereinafter referred to as SMEs). Through the Desk Research method, the analysis of the main indicators of SME development, ways of financing SMEs is carried out. Based on regressive multivariate data analysis and the use of a technical analysis tool, a forecast of the number of people employed in SMEs, the share of GVA in the country's GDP, the share of loans to small businesses, and investments in fixed assets are calculated.
\end{abstract}

Keywords: investment project; financing; investment; source of financing; credit financing; venture financing; venture fund; leasing; leverage leasing; grant financing

Reference to this paper should be made as follows: Aimurzina, B., Kamenova, M., Omarova, A., Bodaubayeva, G., Dzhunusova, A., Kabdullina, G. 2019. Major sources of financing investment projects, Entrepreneurship and Sustainability Issues, 7(2), 1555-1566. http://doi.org/10.9770/jesi.2019.7.2(53)

JEL Classifications: G24, P43

\section{Introduction}

The development of SMEs is one of the strategic objectives of the country, contributing to the promotion of a competitive environment with the prospect of introducing new methods and efficient technologies at enterprises, raising the level of labor productivity, and applying high technologies. In addition to a significant economic role, SME development also plays a social role through the stability of the middle stratum of the population, the 


\section{ENTREPRENEURSHIP AND SUSTAINABILITY ISSUES}

ISSN 2345-0282 (online) http://jssidoi.org/jesi/ 2019 Volume 7 Number 2 (December) http://doi.org/10.9770/jesi.2019.7.2(53)

creation of new jobs, and the reduction of unemployment and poverty (Kowo, et al. 2019; Baltgailis 2019; Azam et al., 2016; Peković, 2017; Bhukuth et al., 2018).

In the Republic of Kazakhstan, the average annual increase in the number of active SMEs over the past 5 years was $2.4 \%$, the number of people employed in SMEs was 2\%, output was 13.2\%, and the share in GRP was 5\% (Statistics Committee).

\section{Research background}

There is a slight annual increase for 2013-2017, number of registered SMEs in the amount of 0.03\%. Table 1 shows the main indicators of the development of SMEs in Kazakhstan for the period 2013-2017.

Table 1. Main indicators of SME development in the Republic of Kazakhstan for the period 2013-2017

\begin{tabular}{|l|l|l|l|l|l|l|l|}
\hline & 2013 & 2015 & 2017 & $\begin{array}{l}\text { Growth } \\
2015 \\
/ 2013, \text { in } \%\end{array}$ & $\begin{array}{l}\text { Growth } \\
2017 \\
/ 2015, \text { in } \%\end{array}$ & $\begin{array}{l}\text { Growth } \\
2017 \\
/ 2013, \text { in } \%\end{array}$ & $\begin{array}{l}\text { Medium } \\
\text { annual } \\
\text { growth } \\
\text { behind } \\
2017 / \\
2013 \Gamma, \text { in } \%\end{array}$ \\
\hline $\begin{array}{l}\text { The number of registered } \\
\text { SMEs, in thousands units }\end{array}$ & 1535,9 & 1481,4 & 1540,5 & $-3,5$ & 3,9 & 0,3 & 0,03 \\
\hline $\begin{array}{l}\text { The number of active } \\
\text { SMEs, in thousands units }\end{array}$ & 888,2 & 1242,5 & 1145,9 & 39,8 & $-7,7$ & 29,0 & 2,4 \\
\hline $\begin{array}{l}\text { Number of people } \\
\text { employed in SMEs, in } \\
\text { thousand people }\end{array}$ & 2576,9 & 3183,8 & 3190,1 & 23,5 & 0,20 & 23,7 & 2,0 \\
\hline $\begin{array}{l}\text { Output, in billion tenge } \\
\text { Share in GDP, in \% }\end{array}$ & 9165,4 & 15699,4 & 23241,1 & 71,3 & 48,0 & 158,6 & 13,2 \\
\hline
\end{tabular}

Source: compiled by authors according to Committee of Statistics of the Ministry of National Economy http://www.stat.kz

Based on the data of the Committee on Statistics of the MNE RK, a trend line was built for the period 2005-2017. (Figure 1), showing the trend of the relationship between the number of people employed in SMEs and the share of GVA of SMEs in a country's GDP. The magnitude of the reliability of the R2 approximation is defined as the square of the correlation coefficient between the level of the dynamic series and time and characterizes the fraction of the variation of the level of the dynamic series, explained by the influence of time. The closer R2 is to 1 , the more significant is the trend equation (JSC Damu). 


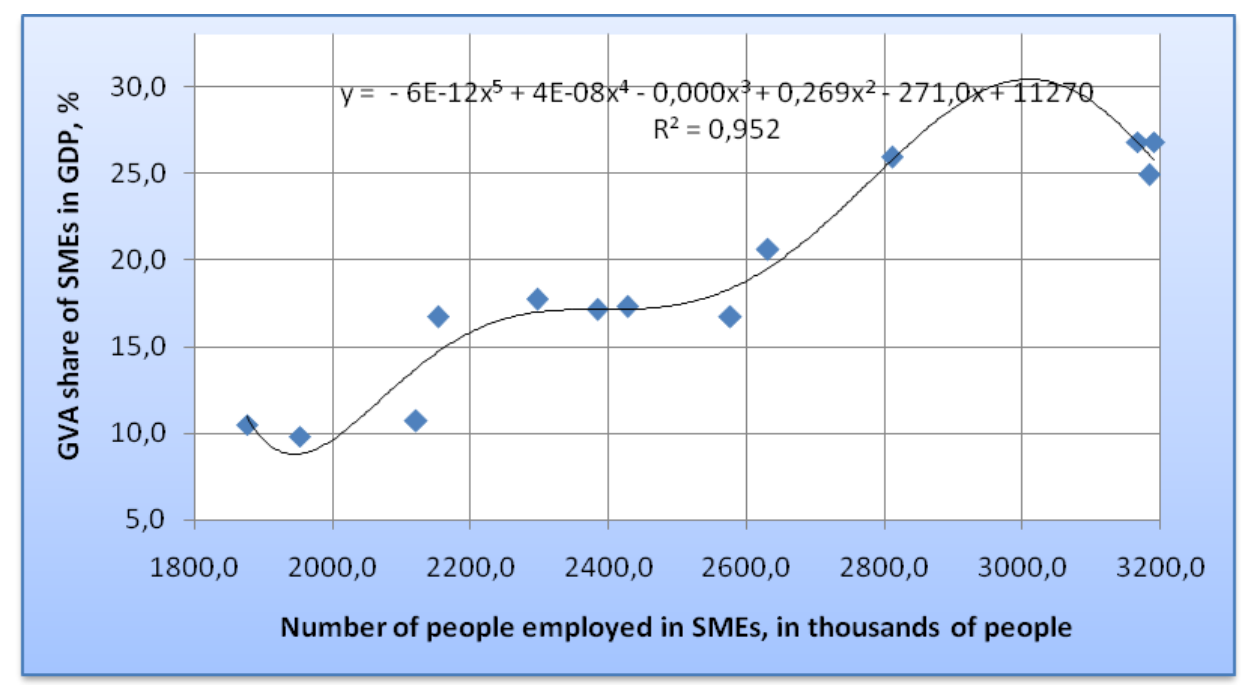

Figure 1. Diagram of the impact of employment in SMEs on the share of GVA in GDP Source: compiled by the authors on the basis of technical analysis

The scatterplot revealed obvious outliers, while the confidence coefficient of the approximation is higher than the optimal value $\mathrm{R} 2=0.9525>0.7$. In view of this, we consider this factor significant. The greater the number of people employed in SMEs, the greater the country's GDP indicators. Prediction in such a model is possible and we see that the point forecast, at first glance, is reliable, since the coefficient of confidence of the approximation is equal to 0.9525 . The polynomial equation for the dependence of the GVA share in GDP on the number of people employed in SMEs is described by the function: $\mathrm{y}=4 \mathrm{E}-16 \mathrm{x} 6-6 \mathrm{E}-12 \times 5+4 \mathrm{E}-08 \mathrm{x} 4-0.0001 \times 3+0.2692 \times 2-$ $271.05 x+112701$.

The forecast values of the number of people employed in SMEs and the share of GVA of SMEs in GDP are given in Table 2, built on the basis of a linear trend line.

Table 2. Forecast of main indicators of SME development

\begin{tabular}{|c|c|c|c|c|c|}
\hline Indicator & 2018 & 2019 & 2020 & 2021 & 2022 \\
\hline Number of people employed in SMEs, in thousand people & 3302,6 & 3415,5 & 3528,4 & 3641,3 & 3754,2 \\
\hline Share in GDP, in \% & 28,3 & 29,8 & 31,2 & 32,6 & 34 \\
\hline
\end{tabular}

Source: compiled by authors according to technical analysis

Based on a technical analysis, a forecast was made of the impact of the number of people employed in SMEs on the share of GVA in GDP (Figure 2).

According to the forecast, the share of the contribution of SMEs to GDP in Kazakhstan in 2022 will be $34 \%$. As compared with developed countries, such as, USA-52\%, Germany-55\%, France -50\%, Denmark-61\%, Italy-68\%, this figure is quite low. 


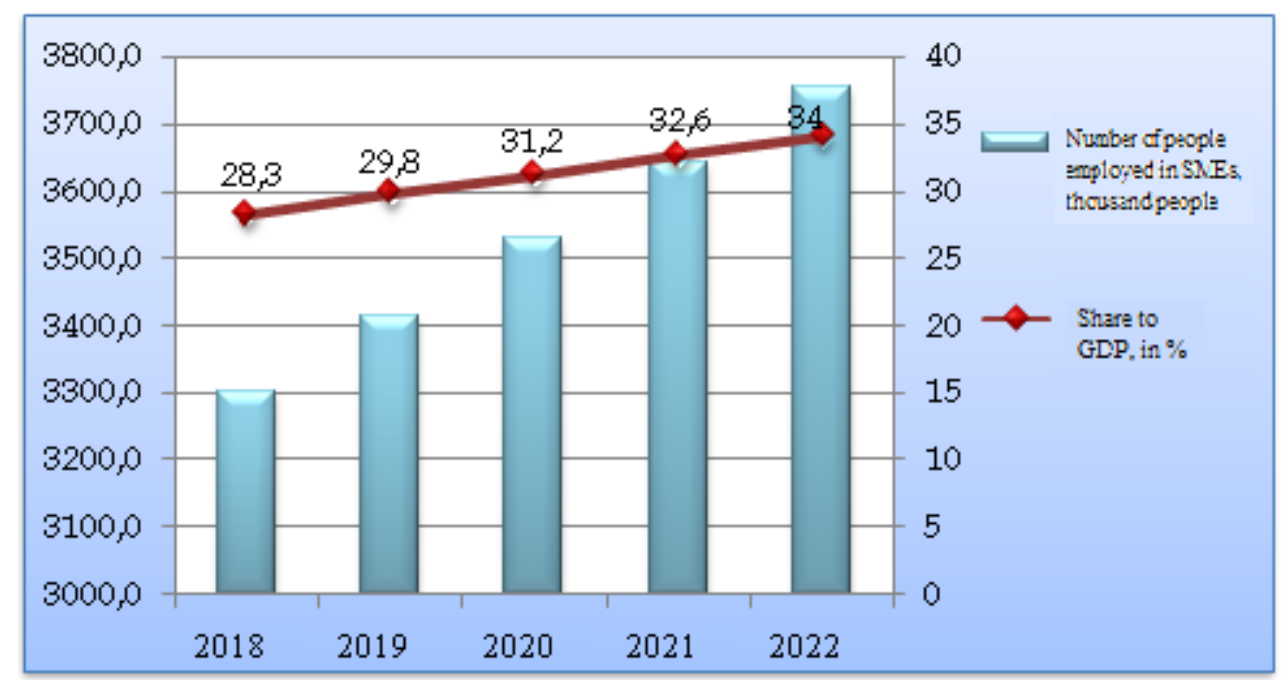

Figure 2. Forecast of the impact of employment in SMEs on the share of GVA in GDP Source: compiled by authors according to technical analysis

Nevertheless, one of the main objectives of the strategic development plan of Kazakhstan is to achieve $50 \%$ of the contribution of enterprises to the country's GDP. To fulfill this task, the state is taking measures to expand and improve government programs to support SME entrepreneurship. One of the main external sources of financing for SMEs is credit financing.

Credit financing is a monetary resource issued by financial institutions on certain conditions (creditworthiness, urgency, solvency) for a certain period.

The creditworthiness of the borrower of an investment project is the ability to accumulate cash flow as a repayment of the loan provided for investment projects based on the basic necessary criteria in terms of assessing the risks and income necessary for a bank to make an effective decision on a project.

In the dynamics of credit financing by second-tier banks, small entrepreneurship can see an average annual growth rate for 2012-2017. amounted to $13.8 \%$, and there is also an increase in the share of credit funds with an average annual growth of $4.2 \%$ in the total amount issued in the country's economy. Table 3 shows the dynamics of credit financing for second-tier banks.

Table 3. Dynamics of credit financing of STB

\begin{tabular}{|c|c|c|c|c|c|c|}
\hline Indicator & 2012 & 2013 & 2014 & 2015 & 2016 & 2017 \\
\hline Loans issued in the economy, in billion tenge & 7249 & 8348 & 10599 & 9351 & 9833 & 12705 \\
\hline $\begin{array}{c}\text { Credits issued to small businesses, in billion } \\
\text { tenge }\end{array}$ & 1050 & 890 & 1198 & 1279 & 1984 & 2789 \\
\hline Share of loans to small businesses, in \% & 14,5 & 10,7 & 11,3 & 13,7 & 20,2 & 21,9 \\
\hline
\end{tabular}

Source: compiled by authors according to Committee of Statistics of the Ministry of National Economy, http://www.stat.kz

Based on the dynamics of actual indicators of loans issued to small businesses in the total volume of loans issued to the economy, as well as applying technical analysis based on an exponential and linear trend line, we will predict the dynamics of loan financing until 2023.

For the indicator "loans issued to the economy" a model of the logarithmic trend line was chosen. The logarithmic trend of the level of the dynamics of loans issued to the economy is presented in Figure 3. 


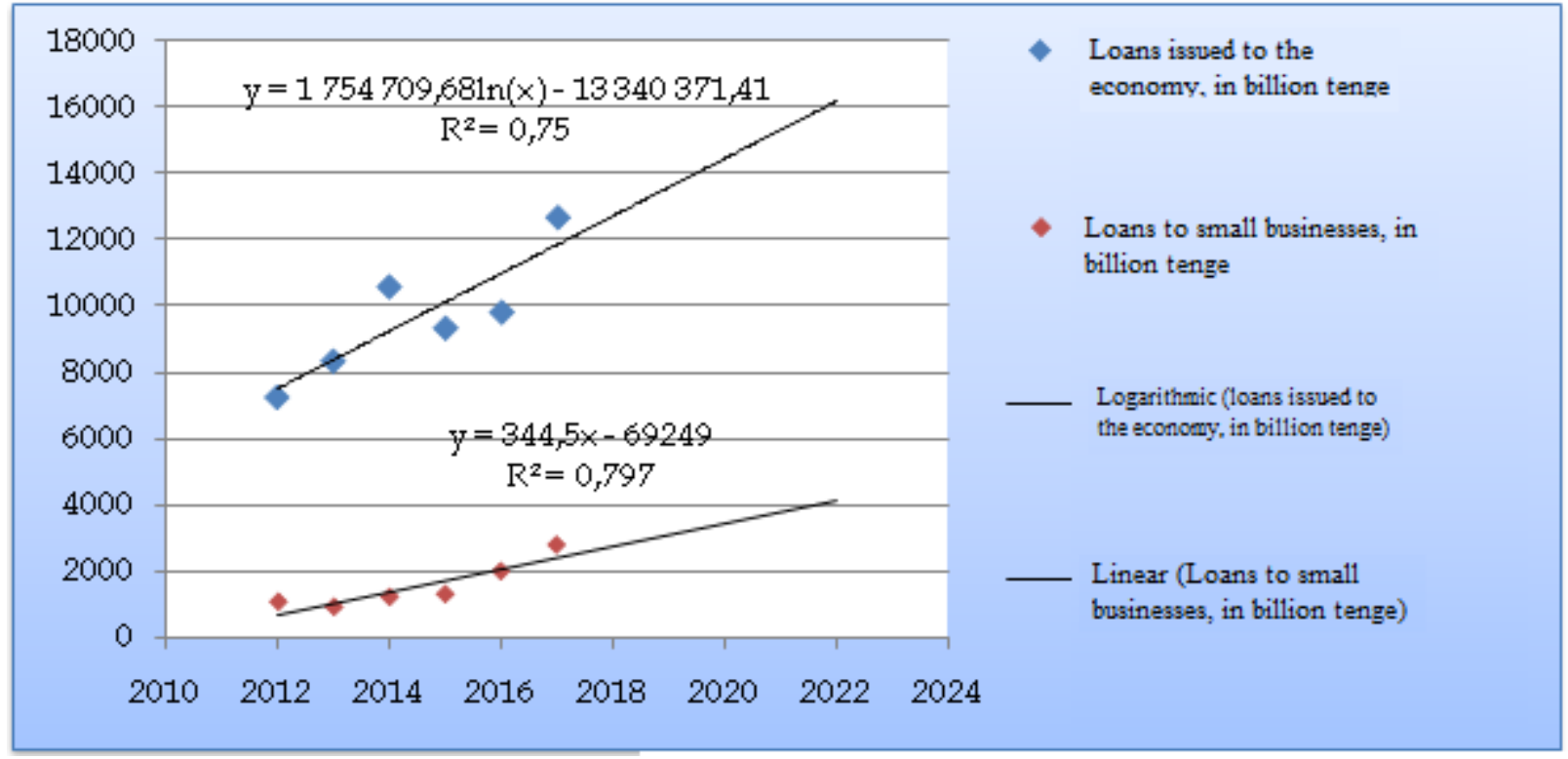

Figure 3. Forecast of the dynamics of loan financing, billion tenge Source: compiled by authors according to technical analysis

\section{Results}

The analysis of this graph shows that the dynamic range model, chosen as a logarithmic trend, in principle adequately describes the real process, the approximation reliability coefficient is 0.75 . Prediction in such a model is possible and we see that the point forecast, at first glance, is reliable.

The logarithmic calculation of the forecast indicator "loans issued to the economy" is represented by the following equation:

$$
y=1754709,68 \operatorname{Ln}(x)-13340371,38(1.1)
$$

where:

$y$ - predicted value of the indicator;

$x$ - actual values of the indicator;

For the indicator "loans issued to small businesses," the optimal model is a linear trend with an approximation coefficient of 0.7975 . Linear calculation of the forecast indicator "loans issued to small businesses" is described by the function:

$$
y=344,51 x-692492(1.2)
$$

where:

$y$ - predicted value of the indicator;

$x-$ actual values of the indicator.

The results of the forecast indicators of loan financing are presented in Table 4. 


\section{ENTREPRENEURSHIP AND SUSTAINABILITY ISSUES}

ISSN 2345-0282 (online) http://jssidoi.org/jesi/

2019 Volume 7 Number 2 (December)

http://doi.org/10.9770/jesi.2019.7.2(53)

Table 4. Forecast of loan financing indicators

\begin{tabular}{|c|c|c|c|c|c|}
\hline Indicator & 2018 & 2019 & 2020 & 2021 & 2022 \\
\hline Credits issued to the economy, in billion tenge & 12727 & 13597 & 14466 & 15334 & 16202 \\
\hline $\begin{array}{c}\text { Credits issued to small businesses, in billion } \\
\text { tenge }\end{array}$ & 2729 & 3074 & 3418 & 3763 & 4107 \\
\hline \begin{tabular}{l} 
The share of loans to small businesses, in \% \\
\hline
\end{tabular} & 21,4 & 22,6 & 23,6 & 24,5 & 25,3 \\
\hline
\end{tabular}

Source: compiled by the authors on the basis of technical analysis

Thus, by 2022, the share of loans to small businesses will be $25.3 \%$ of the total loans issued to the economy. One of the main financial funds to support entrepreneurship is JSC Damu Entrepreneurship Development Fund, which provides financial and non-financial support to SMEs through state programs for both start-up entrepreneurs and operating ones. Loan financing is carried out through certain second-tier banks and leasing companies that are partners of the Fund.

To determine the effectiveness of government programs to support entrepreneurship, we consider the dynamics of the main indicators for the period 2012/2017 (Table 5).

Table 5. Results of credit financing within the framework of state programs under JSC Damu Entrepreneurship Development Fund

\begin{tabular}{|l|c|c|c|c|c|c|}
\hline & 2012 & 2013 & 2014 & 2015 & 2016 & 2017 \\
\hline Number of investment projects, in units & 3560 & 3762 & 5531 & 6186 & 13217 & 11936 \\
\hline Amount of loan financing, in mln. tenge & 331079 & 295419 & 439400 & 523700 & 606000 & 548490 \\
\hline $\begin{array}{l}\text { Production output of SMEs, in billion } \\
\text { tenge }\end{array}$ & 8012 & 9165 & 14605 & 15699 & 16857 & 21148 \\
\hline
\end{tabular}

Source: compiled by the authors based on the annual reports of JSC "Entrepreneurship Development Fund" Damu

The above table clearly demonstrates the steady growth of investment projects by $29.8 \%$ from 2012 . At the same time, the indicators of loan financing are also growing, the average annual increase is $3.3 \%$.

In contrast to loan financing, a venture has several features. According to the terminology Krapivina E.S., a venture fund is an investment fund that is focused on working with innovative enterprises and projects, often start-ups (Krapivina 2014; Kozubíková et al., 2017). Venture financing is a risky activity aimed at the use of scientific advances and technical (technological) innovations that have not yet been used in practice. In the entrepreneurial code of the Republic of Kazakhstan, venture financing refers to activities related to financing persons engaged only in innovative activities, by investing in their authorized capital, acquiring financial instruments issued by them or providing them with a cash loan (Entrepreneurial code).

Thus, venture financing differs in many ways from credit financing. The main differences are the obligatory presence of the innovation component in the investment project, the possibility of attracting funding without providing collateral. Participants in venture financing can be enterprises that are in the early stages of development, as well as existing enterprises that are planning to expand or modernize production (BaranowskaProkop \& Sikora, 2017; Cichy \& Gradoń, 2016). The conditions for providing financing are made on the terms of payment of an investment loan over a long-term investment period with an annual interest rate of $15 \%$ or more or with the participation of the authorized capital of SMEs, while the calculation of the company's value is determined at the preliminary stage of negotiations.

With the entry into force of the new legislation in the Republic of Kazakhstan on venture financing, the demand for venture financing will increase, due to accessibility and simplification of procedures, as well as the creation of a legal framework. The appearance of an agreement on the exercise of the rights of participants in an economic partnership will make it possible to carry out actions related to the management of the partnership, through 


\section{ENTREPRENEURSHIP AND SUSTAINABILITY ISSUES}

ISSN 2345-0282 (online) http://jssidoi.org/jesi/ 2019 Volume 7 Number 2 (December) http://doi.org/10.9770/jesi.2019.7.2(53)

participation in voting at a general meeting of participants. In addition, participants in the partnership may provide for compensation for property losses due to the impossibility of meeting their obligations (Law of the Republic of Kazakhstan 2018). The concept of "venture manager" is introduced, which is engaged in the management of assets of the venture fund under the terms of the contract concluded with it. The opening of the international technology park of IT start-ups "Astana Hub", being a platform in order to attract venture capitalists, business angels, will allow SMEs to develop in high-tech innovation spheres.

The investment portfolio of the main venture capital funds in the Republic of Kazakhstan is presented in Table 6. In compiling the investment portfolio, annual reports for 2017 were used by JSC NATAT, JSC Kazyna Capital Management (Annual report of JSC NATR and JSC Kazyna Capital).

Table 6. Investment portfolio of main venture funds in the Republic of Kazakhstan

\begin{tabular}{|c|c|c|c|}
\hline № & Name of the direct investment fund & Venture fund & $\begin{array}{c}\text { Venture Fund } \\
\text { Investments, in million } \\
\text { tenge }\end{array}$ \\
\hline 1 & JSC «Areket» & \multirow[t]{5}{*}{ JSC «NATR» } & 264,6 \\
\hline 2 & JSC «Delta Tehnology» & & 1320 \\
\hline 3 & Wellington Partners Ventures III Technology Fund L.P. & & 1329 \\
\hline 4 & Flagship Venture Fund & & 1281 \\
\hline 5 & Vertex III Venture Fund & & 674 \\
\hline 6 & Aureos Central Asia Fund & \multirow{13}{*}{$\begin{array}{c}\text { JSC «Kazyna Capital } \\
\text { Management» }\end{array}$} & 1961 \\
\hline 7 & Wolfensohn Capital Partners (WCP) & & 9213 \\
\hline 8 & ADM Kazakhstan Capital Restructuring Fund (KCRF) & & 18315 \\
\hline 9 & Russian - Kazakh Fund of Nanotechnology (RKFN) & & 9250 \\
\hline 10 & Falah Growth Fund (FGF) & & 18500 \\
\hline 11 & Kazakhstan Growth Fund (KGF) & & 14800 \\
\hline 12 & Macquarie Russia and CIS Infrastructure Fund (MRIF) & & 11100 \\
\hline 13 & CITIC-Kazyna Investment Fund I (CKIF) & & 37000 \\
\hline 14 & Almex-Baiterek Fund (ABF) & & 10323 \\
\hline 15 & Islamic Infrastructure Fund (IIF) & & 1110 \\
\hline 16 & Baiterek Venture Fund (BVF) & & 14134 \\
\hline 17 & Kazakhstan Infrastructure Fund (KIF) & & 37000 \\
\hline 18 & DBK Equity Fund C.V. & & 1106,3 \\
\hline
\end{tabular}

Source: compiled by the authors based on the annual reports of JSC "Entrepreneurship Development Fund" Damu

Forming a legal framework conducive to resolving relations between venture capital market participants, creating a mechanism for state participation in financing venture funds, through development institutions and national companies, will stimulate an increase in venture capital investments in innovative projects, which will increase the country's GDP indicators in a certain way.

JSC "National Agency for Technological Development" is the main operator of the program for the grant financing of innovative projects. One of the main programs is "Innovation Grants".

Innovation grant - budget funds provided to the subjects of industrial and innovative activities on a grant basis for the implementation of their industrial and innovative projects in the framework of the priority areas for the provision of innovative grants (Concept of innovative development). Since 2017, the program has been amended, namely, the grant limit has been increased to 500 million tenge, requirements for grant recipients have changed regarding the presence of 3-3 years of business experience, as well as their own participation in the project. In addition, the procedure for reviewing and filing an application has been simplified, and the time periods for examination have been reduced. 


\section{ENTREPRENEURSHIP AND SUSTAINABILITY ISSUES}

ISSN 2345-0282 (online) http://jssidoi.org/jesi/

2019 Volume 7 Number 2 (December)

http://doi.org/10.9770/jesi.2019.7.2(53)

According to the results of 2017, out of 208 grant applications, 9 inno- vation grants were approved, worth a total of 1,687 billion tenge, $24 \%$ of which were directed to technology commercialization, $34 \%$ to the technological development of existing enterprises, $42 \%$ to the development of industries. In terms of industries, the leading place is occupied by the development of information and communication technologies, then progressive technologies in the agro-industrial complex, the third and fourth places are engineering and advanced technologies in construction.

Thus, the state stimulates the development of innovative entrepreneurship, creating favorable conditions for the introduction of new advanced technologies and innovative solutions.

One of the lending instruments for SMEs is leasing financing. Leasing is a long-term lease of machinery, equipment, vehicles, as well as industrial facilities, that is, a form of investment (Zhuirikov 2017). The main difference between leasing financing and credit is the lack of collateral, instead the security is the registration of the lessor's ownership of the property. Also after payment of all leasing payments, the lessee draws ownership of the acquired assets.

According to Gazman V.D. Leasing should be divided into: financial, operational, leverage-leasing, leaseback (Gazman 2013). The author of another work cites another type of leasing - leasing "in package", a financing system in which buildings and structures are provided on credit, and equipment is given to the lessor under a lease agreement.

According to Zhuirikov K.K. leverage leasing is a financial leasing in which a larger share of the leased asset is leased to a third party (Zhuirikov 2017).

According to the Statistics Committee of the MNE RK, the following types of leasing prevail in the Republic: returnable, full, clean.

Returnable leasing is one of the types of leasing financing, which provides for the sale by the supplier of equipment, equipment, buildings, etc. on the terms of returning this object to leasing as a lessee (Braginets 2013). Full leasing, in addition to leasing equipment, equipment, buildings, provides technological support, including repair and maintenance services for leasing objects, performed by the lessor (Arystanbaeva 2016).

In the case of net leasing, technological service is performed by the lessee (Adambekova 2014).

The amount of leasing payments received in 2017 amounted to 163,758 million tenge, of which 56\% falls on Astana, $41 \%$ on Akmola region.

Table 7. The main indicators of financial leasing at the end of 2017

\begin{tabular}{|c|c|c|}
\hline \% financial leasing rate & The cost of contracts, in thousand tenge & Quantity, in units \\
\hline before 10\% & 67872980 & 1271 \\
\hline up 10\% to 14\% & 23739913 & 78 \\
\hline over 14\% & 132438390 & 2952 \\
\hline
\end{tabular}

Source: compiled by authors according to Committee of Statistics of the Ministry of National Economy, http://www.stat.kz

One of the factors affecting the development of the leasing market is investment in fixed assets. In the dynamics of 2005/2017 growth of investments in fixed assets amounted to $72.3 \%$, with an annual increase equal to $6 \%$. Applying a technical analysis of forecasting based on a linear trend line, described above, the predictive values of the indicator were calculated. By constructing a scatterplot and trend lines with an approximation confidence factor of R2 =0.98, we obtain the forecast until 2022 (Figure 4) (EBRD 2018). 
ISSN 2345-0282 (online) http://jssidoi.org/jesi/ 2019 Volume 7 Number 2 (December) http://doi.org/10.9770/jesi.2019.7.2(53)

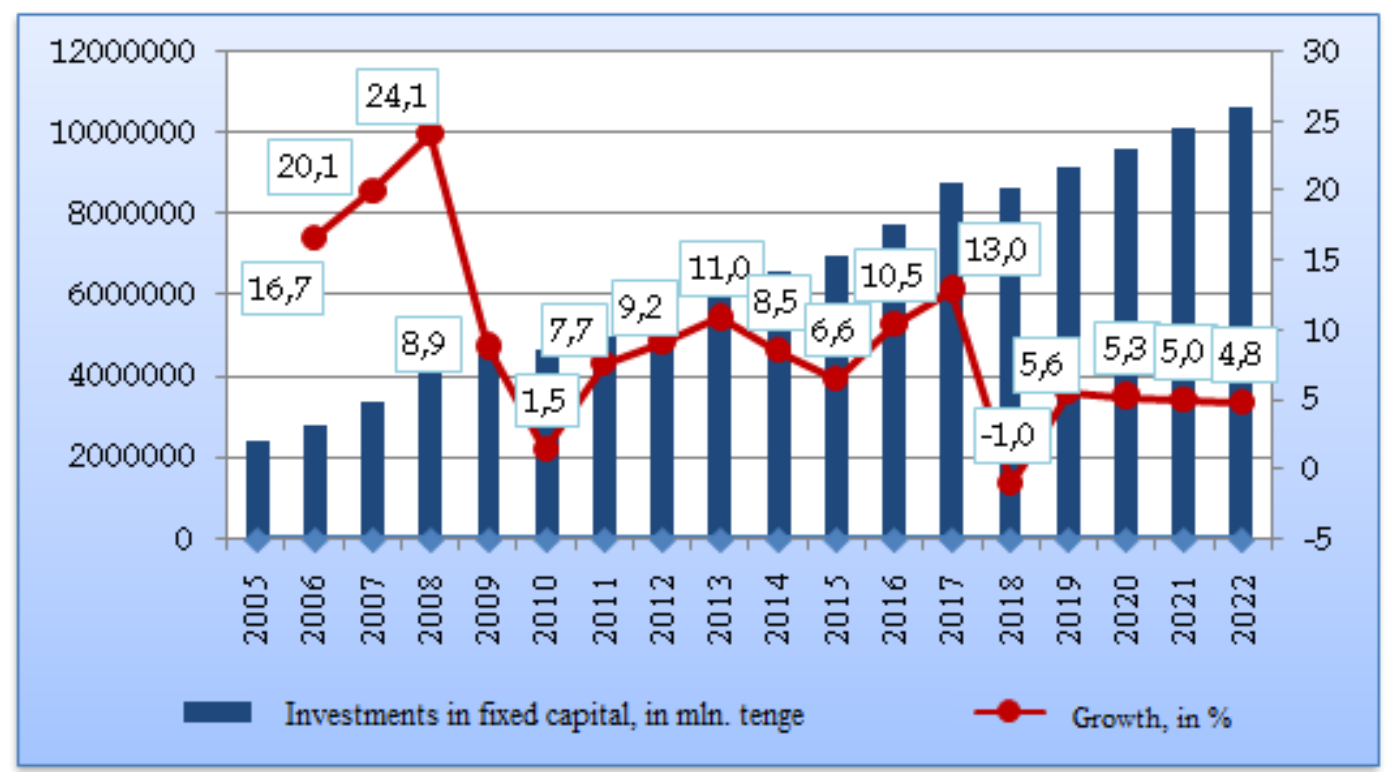

Figure 4. Forecast of investment in fixed capital, in mln. tenge

Source: compiled by the authors on the basis of technical analysis

The average annual increase in investments in fixed assets over the period 2005-2022 will be $28.2 \%$, in physical terms 10,625,700 million tenge.

Another fundamental factor influencing leasing demand is the degree of depreciation of assets of enterprises (Figure 5).

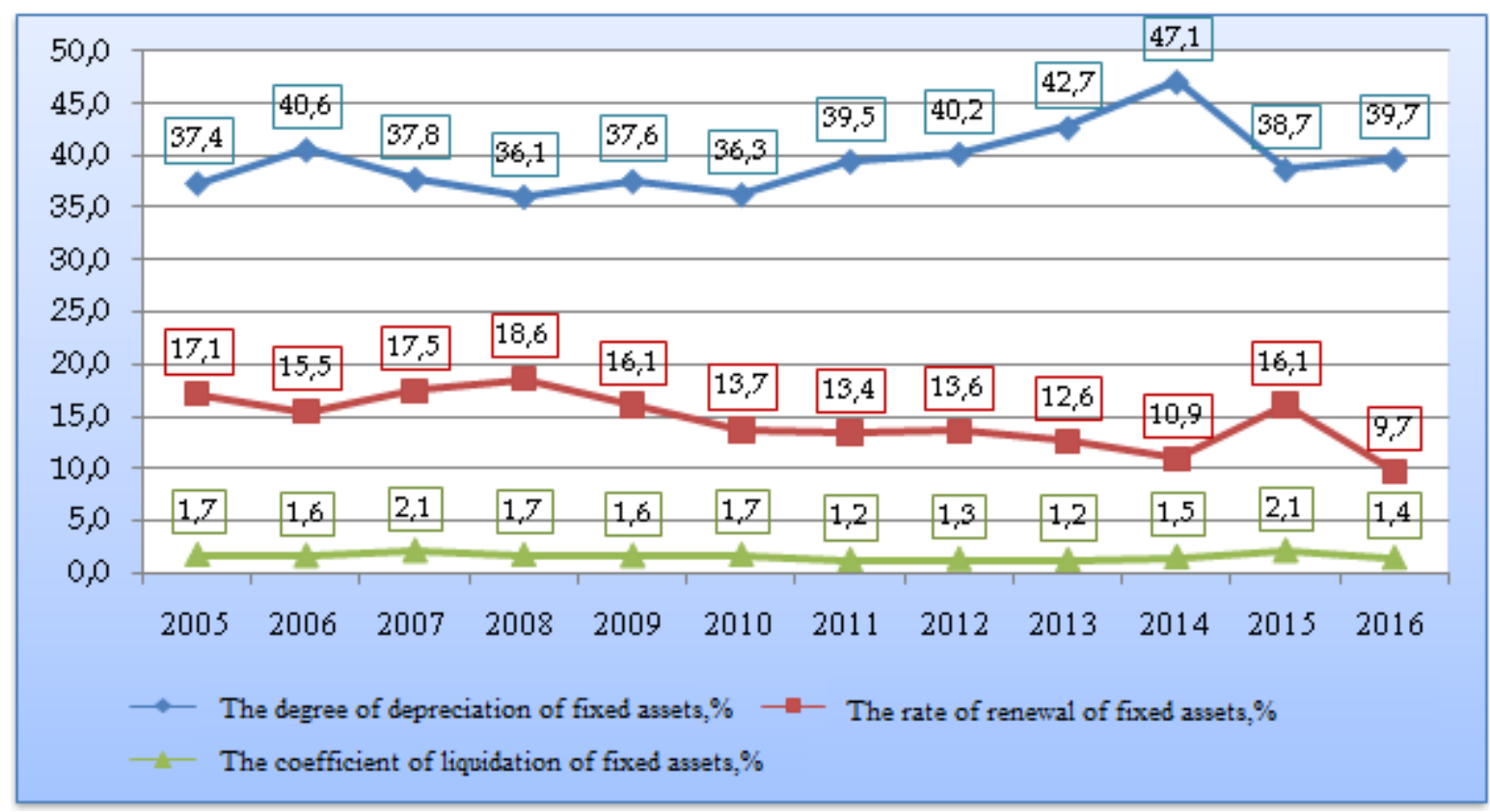

Figure 5. Basic indicators of fixed assets, in \%

Source: compiled by the authors on the basis of data from the Committee on Statistics of the Ministry of National Economy of the Republic of Kazakhstan: http://stat.gov.kz/ 


\section{ENTREPRENEURSHIP AND SUSTAINABILITY ISSUES}

ISSN 2345-0282 (online) http://jssidoi.org/jesi/

2019 Volume 7 Number 2 (December)

http://doi.org/10.9770/jesi.2019.7.2(53)

In the Republic, the degree of wear at the end of 2016 was $39.7 \%$ versus $38.7 \%$ a year earlier. The coefficient of liquidation of fixed assets at the same time amounted to only $1.4 \%$, which speaks of asset upgrades and write-offs. Also, according to the Statistics Committee of the MNE RK, the total value of financial leasing contracts for 2017 increased by $34 \%$ compared with the previous year and amounted to 224 billion tenge (Doing business 2015).

Thus, in the development trend of leasing financing growth is noted, leasing assets becomes an effective way to update the production capacity of enterprises, due to the decline in the share of credit or equity (Dzhaksybekova 2016).

\section{Conclusions}

In addition to traditional methods of attracting funding, there are also modern methods. A striking example is the crowdfunding system of attracting investment (from the English. "Crowd" - group, "funding" - financing), that is, funding from a large number of people.

In Kazakhstan, this type of financing appeared in 2013, however, active work began recently. Submitted by the crowdfunding platforms, provide services to attract funding for the implementation of business ideas from around the world.

In conclusion, we would like to note that the considered sources of external financing are not the only ones, there are many other ways of financing, including various combinations and options for the implementation of investment projects. The country's economic growth is directly dependent on the development of SMEs and on a favorable investment climate. "The development of small and medium business is the main tool of industrial and social modernization of Kazakhstan in the twenty-first century".

\section{References}

Adambekova, A. A. 2014. The financial market of Kazakhstan: interaction and development prospects of its segments. Almaty: Economics. 286 p.

Annual reports of JSC Kazyna Capital Management www.kcm-kazyna.kz

Annual reports of JSC NATR www.natd.gov.kz

Arystanbaeva, S. S. 2016. Problems of the formation and use of financial resources: orientation towards country competitiveness. Almaty: LEM. $140 \mathrm{p}$.

Azam, M., Haseeb, M., Samsudin, S. 2016. The impact of foreign remittances on poverty alleviation: global evidence. Economics and Sociology 9(1), 264-281. https://doi.org/10.14254/2071-789X.2016/9-1/18

Baltgailis, J. 2019. The issues of increasing the effectiveness of teaching comparative economics. Insights into Regional Development, 1(3), 190-199. https://doi.org/10.9770/ird.2019.1.3(1)

Baranowska-Prokop, E., \& Sikora, T. 2017. Innovativeness and success perception of Polish small- and medium-sized international new ventures. Journal of International Studies, 10(3), 134-146. https://doi.org/10.14254/2071-8330.2017/10-3/10

Braginets, M.V. 2013. Analysis of foreign experience of state support for the development of innovative activities. Bulletin of the Russian Academy of Natural Sciences, 15(3), 22-25. 


\section{ENTREPRENEURSHIP AND SUSTAINABILITY ISSUES}

ISSN 2345-0282 (online) http://jssidoi.org/jesi/

2019 Volume 7 Number 2 (December)

http://doi.org/10.9770/jesi.2019.7.2(53)

Bhukuth, A., Roumane, A., Terrany, B. 2018. Cooperative, Human Capital and Poverty: a Theoretical Framework. Economics and Sociology, 11(2), 11-18. https://doi.org/10.14254/2071-789X.2018/11-2/1

Cichy J., Gradoń W. 2016, Innovative economy, and the activity of fi nancial market institutions. Case of Poland, Journal of International Studies, 9(1), 156-166. https://doi.org/10.14254/2071-8330.2016/9-1/11

Committee of Statistics of the Ministry of National Economy http://www.stat.kz

Concept of innovative development of the Republic of Kazakhstan until 2020. www.natd.gov.kz

Dzhaksybekova, G.N. 2016. Financial monitoring. Estimation of company value. Almaty: Ereket-Print. 339 p.

Entrepreneurial Code of the Republic of Kazakhstan. 2015.

Entrepreneurs on the conditions of doing business. 2015. Institute for Political Decisions. http://www.ipr.kz/projects/2/1/97

Gazman, V. D. 2013. Leverage Leasing: Financing Large Investment Projects. HSE Economic Journal, 1(7), 45-49.

Kazakhstan: Business Environment and Enterprise Performance Survey. European Bank for Reconstruction and Development (EBRD) and the World Bank. 2018. http://www.worldbank.org/

Krapivina, E.S. 2014. Financing the development of the information society by venture funds in the Republic of Kazakhstan. Young scientist, 5(11), 272-274.

Kowo, S. A., Adenuga, O. A. O., Sabitu, O.O. 2019. The role of SMEs development on poverty alleviation in Nigeria, Insights into Regional Development, 1(3), 214-226. https://doi.org/10.9770/ird.2019.1.3(3)

Kozubíková, L., Dvorský, J., Cepel, M. \& Balcerzak, A. P. 2017. Important characteristics of an entrepreneur in relation to risk taking: Czech Republic case study. Journal of International Studies, 10(3), 220-233. https://doi.org/10.14254/2071-8330.2017/10-3/16

Law of the Republic of Kazakhstan. 2018. On Amendments and Additions to Some Legislative Acts of the Republic of Kazakhstan on Venture Financing Issues.

Peković, D. 2017. The effects of remittances on poverty alleviation in transition countries. Journal of International Studies, 10(4), 37-46. https://doi.org/10.14254/2071-8330.2017/10-4/2

Report on the state of development of SMEs in Kazakhstan and its regions JSC Damu Entrepreneurship Development Fund JSC. www.damu.kz

Statistics Committee of the Ministry of National Economy of the Republic of Kazakhstan www.stat.gov.kz

Zhuirikov, K.K. 2017. Journal Banks of Kazakhstan. Methods and sources of financing investment projects, 7(12), 52-57. 
Baglan AIMURZINA is Doctor of Economic Sciences, Professor of Kazakh University of Economics, Finance and International Trade, Astana, Kazakhstan. Research interests: finance, taxes, investments, budget, credit.

ORCID ID: orcid.org/0000-0003-2625-7989

Mazken KAMENOVA is Doctor of Economic Sciences, Professor of Kazakh University of Economics, Finance and International Trade, Astana, Kazakhstan. Research interests: investments, economics, management, production.

ORCID ID: orcid.org/0000-0003-2018-521X

Ainura OMAROVA is $\mathrm{PhD}$, Associate Professor of Karaganda Economic University of Kazpotrebsoyuz, Karaganda, Kazakhstan. Research interests: investment, innovation, human resources.

ORCID ID: orcid.org/0000-0001-9808-4908

Gulmira BODAUBAYEVA is Candidate of Economic Sciences, Associate Professor of University of International Business, Almaty, Kazakhstan. Research interests: investments, economics, management, production.

ORCID ID: orcid.org/0000-0001-5697-4283.

Asel DZHUNUSOVA is Master of Kazakh University of Economics, Finance and International Trade, Astana, Kazakhstan. Research interests: finance, taxes, investments, budget, credit.

ORCID ID: orcid.org/0000-0001-0922-5030

Gulmira KABDULLINA is Doctor of Economic Sciences, Professor of South Ural State University (National Research University), Chelyabinsk, Russia. Research interests: investment, innovation, human resources.

ORCID ID: orcid.org/0000-0002-0215-1502. 